\title{
STORIES, STONES, AND MEMORIES IN THE LAND OF DORMANT RECIPROCITY. OPENING UP POSSIBILITIES FOR RECONGILATION WTH A POLITICS THAT WORKS TENSIONS OF DISSENSUS AND GONSENSUS WITH CARE
}

\section{BY BRITT KRAMVIG AND HELEN VERRAN}

\section{ABSTRACT}

In this article we address storytelling as an epistemic practice and ask if/how storytelling can become a tool for reconciliation, specifically in relation to violent acts of past and present colonising. In Sápmi, telling stories is essential in everyday life. Stories are told to engage actively with questions, as opposed to referring to an absent past, or to bringing forth explanations or arguments. Stories are told to bring past events and knowledge on how to live well and respectfully with both human and non-human beings into the present knowledge. Enacting in stories is also a central part of recalling how earthlings can live together in the Sámi landscape. In this article, stories on sieidies (Sámi sacrificial place) are addressed. We make evident the existence of a land of dormant reciprocity in the Norwegian present, and establish sieidies as ontologically multiple. We will propose that stories, with their implicit or explicit recognition of this multiplicity, can work in the ongoing reconciliation addressed by the Norwegian government and the Sámi Parliament. 


\section{INTRODUCTION}

In this article, we address storytelling as an epistemic practice, and ask whether storytelling can become a tool for reconciliation, specifically for violent acts of past and present colonisation. In Sápmi, telling stories is essential in everyday life. Stories are told to actively engage with questions, as opposed to referring to an absent past or bringing forth explanations or arguments. Stories are also told to bring past events and knowledge on how to live well and respectfully with both human and non-human beings, into present knowledge. Enacting in stories is a central part of recalling how earthlings can live together in the Sámi landscape. This article addresses stories about sieidies, in particular Sámi secret stones. We make evident the existence of a land of dormant reciprocity in the Norwegian present and establish sieidies as ontologically multiple. We propose that stories, with their implicit or explicit recognition of this multiplicity, can act in the ongoing reconciliation addressed by the Norwegian government and the Sámi Parliament.

Stories and the making way for local storytelling, have been used as a methodology in the preparatory phase of the Norwegian truth and reconciliation commission (constituted in June 2018). They are also considered to be a tool for locally embedded enactments of living well together. Sieidies or Sámi secret stones mark and sign the landscape as Sámi. Our interest is ontological, as we have learned that sieidi belong to the land of dormant reciprocity as much as to the embodied here and now of the Sámi present, and the archaeological present.

Recognition of dormant reciprocity as being embedded in and as being the landscape, informs an emergent politics of memory in contemporary society. Sieidies here become the object of local storytelling. So do multiple other Sámi practices. They also are the object of academic stories of scholars concerned with shamanism (Fonneland, 2017), tourism (Olsen, 2017), nature and art (Kramvig \& Pettersen, 2016) and heritage (Lund, 2015; Mathisen, 2010). This chapter is an intervention in the epistemic politics of contemporary Sámi-Norwegian public life. Our experimentation in epistemic practices is inspired by Wintereik and Verran (2012). Their description of the analysis, which is carried out by flip-flopping between metaphysical commitments, is central. This enables contingent, simultaneous recognition of what are otherwise incommensurable claims. Reconciliation is possible through acceptance 
of the possibility of doing difference differently. We engaged with specific localities, specific written or oral stories, and experiences of land, animals, paths and other participants that we engaged with in and through these landscapes, to enact the land of dormant reciprocity.

Jackson (2002) argues that storytelling events provide insights into the ways that people evaluate, discuss, and negotiate social and ethical strategies for making communal life viable. They provide answers to questions such as 'How are we to think about the past?' and 'How are we to talk about history?' A linearity of thinking is frequently brought forward to answer these questions. The 'need to put the past behind us' is, in public debate, part of the argument promoted, including in the Norwegian/Sámi reconciliation process. We argue that there is a need to think differently about the past, and that there is a need to accept that the past remains in place. As Oakeshott (1933) argued, the past is not a different world. There are not two worlds. 'The world of past happenings and the world of our present knowledge of those past events - there is only one world, and it is the world of present experience' (Oakeshott, 1933, p.108). What this implies to our thinking around what 'telling the truth' will become in reconciliation, is important. The question of how to facilitate generative truth telling therefore looms large.

The need to tell the full story has become a major aim in public debate. This has been facilitated by creating a space for people in multiple communities to tell how Norwegian polices of 'norwegianisation' have for centuries affected the Sámi population. The concept of colonization was not academically or politically considered to be useful before the enactments in recent years of a new generation of indigenous artists and scholars. They were inspired by and connected to the ongoing exchange between communities of indigenous/ non-scholars and artists on a global scale. Telling stories of truth was launched in multiple Sámi communities as a central objective of the ongoing public meetings. The public meetings were organized by the Sámi Parliament as part of establishing the mandate for the future work of the Truth and Reconciliation committees. As Jackson (2002) argues, storytelling serves as a strategy for transforming private into public, and through this sustaining human agency in the face of disempowering circumstances. Jackson, focuses on how we rework reality through making and telling stories to make reality bearable. Storytelling may be a coping strategy. It is a world-making practice. In telling stories we reclaim a say in the way that our lives unfold (Kramvig \& Verran, 2016). 
We will argue that storytelling can become a tool for reworking the colonial past, and can therefore change our experience of it. We, however, need to expand our way of thinking about stories. We should not merely focus on stories as products, but also on storytelling as an intersection in reciprocity. Storytelling can therefore inform an emergent politics of memory and enact landscapes of remembrance. This emphasises the importance of not only the substance of the stories, but also the very act of participating in a shared event. It also emphasises how this event brings our attention to our sense of beingwith-others, so promoting relation-weaving and world-making in which the past and the future are recalled as well as remade. These acts of participation also require both an audience and a storyteller, in an interactive relationship of call and response. The storytelling event itself realizes, both socially and dialogically, an ideal of tolerant solidarity in difference (Jackson, 2002). We argue that telling stories is caring for those within the event of the stories, and that are recalled into being. The past can be touched through objects, but also through stories.

There are movements of care involved in telling. Caring practices, as Mol, Moser \& Pols (2010) argue, move us beyond rationalist versions of the human being. Care involves embodied practices. Care in practice is not restricted to a specific domain or site, but should be understood as being a doing, a mode, or a style. Good care is always a collective achievement, and involves 'persistent tinkering in a world full of complex ambivalence and shifting tensions' (Mol et al., 2010, p.14). Care as attuned attentiveness, and adaptive tinkering, asks for an embodied engagement with the human, non-human, the regulation of traditions, technological tools, landscapes, and authorities. Joks \& Law (2016) have argued that we need to be concerned not only with what or whom to care for, but also how we care. Different caring practices and stories of care articulate differences in modes of knowing.

\section{SÁMI LANDSCAPE}

We, in this chapter, engage with Sámi landscape at which siedies are attended. We show a form of experimental scholarly work which we propose as an invention of practices that have epistemic salience. As academic epistemic practices, they are novel. We aim to bring sieidies to life in an ontologically reflexive post-colonial knowing of Sámi sacred sites and landscapes. Heinämäki 
\& Herrmann (2017) argue that, for many Indigenous Arctic communities, sacred natural sites are embedded in spirituality, cultural practices and belief systems. Respect for and access restrictions to them have therefore often led to well-conserved areas within otherwise degraded Arctic environments (Heinämäki \& Herrmann, 2017, p.1). Sacred sites have, therefore, played an important role in nature conservation and protection. Landscape-based protected areas would not exist without the profound cultural and spiritual values assigned to them by the indigenous communities to which they belong. Myrvoll (2017) highlight that there are well known stories within the local communities that illustrate respectful behaviour towards Sámi sacred sites. They also illustrate the punishment that follows where these locally known principals of respect are broken. Reinert (2016) focuses on sacred sites as the scope of existing relational imaginaries, and with the possible role of stone-human relations in the ontological politics of a present moment defined by the unfolding collapse of planetary ecosystems.

The question posed in this chapter is, however, different. It is still inspired by the need not only for new research imaginaries, addressed by Reinert (2016), but also the need for new ethnographic practices, inspired by Spivak (1993) and Kuokkanen's (2010) request to do more homework, in this case fieldwork. Modern school homework implies carrying out class work outside of school. Our notion of fieldwork as homework bears implications of attending more closely to what it is sieidies bring together in being in place and as a place. Sieidies are stones that have multiple enactments. These are performed in archaeology, and feature as inscriptions on maps in hundreds of places across the traditional territory of the Sámi people. There are material interventions in the landscape of the Nordic countries. More than 500 Sámi sacred sites in Sápmi are 'told' of as having been used from the Late Iron Age until recent times (Manker, 1957; Bergman et al., 2013; Mulk, 1996; Äikäs et al., 2009; Äikäs \& Salmi, 2013). These have also, more recently, appeared in cultural studies of Sámi people or landscapes (Mathisen, 2010; Reinert, 2016; Østmo \& Law, 2017) and in Indigenous studies and Law (Heinämäki \& Herrmann, 2017; Myrvoll, 2017). Sieidies dwell in the landscape, often at places that are distinct and recognizable. Tracks made by both human and animals often form entrances to the stones, and their stories are told in fragments of local texts and storytelling events. You often need to know the community or the people to learn of the presence of the stones. They are not easily talked about. The people we talked to spoke of feeling an absence of the words necessary to tell these stories in respectful ways. 
Sieidies have, for a very long time, not been central to the politics of knowing. Not in Sápmi, nor in the north in general. They have been connected to the practice of shamanism, which was performed in the past. Not remembering the sieidies and where and how they figured in the landscape, is therefore mostly a result of colonial politics. In this chapter we argue that siedies provide possibilities for decolonizing epistemic practices through being an entrance into the landscapes, the remembrance of heritage, and to attending to the healing capacity of the landscape, and through this participate in addressing the landscape as Sámi.

Sámi material culture has significant regional differences. The contemporary way of enacting these places further multiplies the places. Mathisen (2010) argues that there are different individual actions in relation to Sámi sacrificial stones. These appear in narratives, missionary reports, and research. He also argues that we need to focus upon how the ownership of such cultural heritage sites can lead to them becoming sites of intercultural conflict and to destruction or plunder. This can subsequently lead to these becoming sites of ethnic revival, and to claims of repatriation and heritage status. Some even become more touristic attractions, where the act of leaving a gift behind can be performed in new and multiple ways (Olsen, 2017). Fonneland (2017) argues that the Sámi claim that sieidies are secret sites, needs to be viewed as being contemporary shamanism in which parts of pre-Christian practices and symbols are incorporated into new contexts and interpretive frames. We strongly believe that these are interesting arguments. We, however, also believe that these positions hold on to an ontological politics that does not take seriously the ontological differences that exist between Sámi and modern landscape practices.

We will, in this article, use the concept of analytic homework as fieldwork at two different sites. One in the municipality of Guovdageaidnu, or Kautokeino and very much embedded in the Sámi traditional way of knowing and living with the land. The other in South of Troms, where Sámi heritage is being reclaimed and revitalized as we write. We have been walking the paths in both these areas on the land previously used by both animals and people, and have been introduced to specific sieidies, these introductions differing. Sieidies have for a long time dwelt in and been the land of (forgotten) memories by the people that once considered these lands their home. There are a few exceptions to this, which you can read about in this article. This is due to the Christianisation of the Sámi that was part of national politics from 1500 and onwards. 
Sámi identities, practices and knowledge tradition, however, survived in some areas within the new Sámi religious movement of Laestadianism in the era of intensified colonisation from the 1900 onwards (Minde, 1998). Miller (2007), exploring the cultural and historic context of Sámi healing practices, argues that Sámi healers today may be connected historically to the noaidi (shaman) of the past. They cannot, however, be directly identified with the noaidi. The healers consider themselves to be Christian and conceive of their healing gift as being embedded in a special connection with both God and the community. A healer, having inherited the gift, is guided by their ability to diagnose bodily experiences, visions and/or thoughts. Miller (2007) argues that the leading principle of Sámi healers (their 'inside' knowledge) is that a 'correct connection' is required.

People wish, in other cases, to re-learn from and engage with these stones as sacred places, in what contemporary academic discourse often calls new-shamanistic movements. Stones are spiritual actors in this that must be respected. The stones in texts ask for an offering, and provide bodily healing and comfort in times of despair. In some of the local Norwegian discourse, they are brought into the present with what we would argue are neo-colonial stories that mark these as more a part of the Norwegian than the Sámi heritage. We present ethnographic stories in this chapter that account for these discourses. However we, before telling the stories, present a short section on methodology in indigenous studies.

\section{DOING ANALYTIC HOMEWORK AND STAYING WITH THE ONTOLOGICAL TROUBLE}

Haraway (2016) argues that staying with the trouble requires 'making oddkin; that is, we require each other in unexpected collaborations and combinations, in hot compost piles. We become-with each other or not at all. This kind of material semiotics is always situated, someplace and not noplace, entangled and worldly' (Haraway, 2016, p.4). We strongly believe that analytic homework is required to achieve this. Homework was introduced by the feminist postcolonial author Spivak, who linked the notion of homework with the unlearning of one's privilege and of 'unlearning one's learning'. Spivak urges academics to learn how to behave as a subject of knowledge within the institution of neocolonial learning (Danius, Jonsson, \& Spivak, 1993). We should 
all be aware. Undoing one's privilege is, however, not an easy task at all. She is also not specific on how to do this in practice. She claims that it requires the addressing of the privileges that come with gender, class, ethnicity and the historical circumstances of the contemporary privileged position. Unlearning also implies an analysis of the naturalization of privileges, the 'moves of innocence' and the right to not know, as is also addressed by Hannah Arendt. The Sámi scholar Kuokkanen (2010) argues, in line with Spivak, that academic neglect of indigenous epistemic practices means that homework in indigenous epistemes has to begin from an even more basic level: the level of the researchers' own beliefs, biases and assumptions. It has to start from acknowledging the existence of 'the indigenous', the people, their epistemic practices and how they are configured in the geo-political past and present (Kuokkanen 2010, p.67).

Decolonization could be a concept of the means for unlearning one's learning, for example by walking the land and recalling the stories (Jernsletten, 2010). Jernsletten (2012) suggests that claiming that knowledge does not belong to the academic author, but to the land and the multiple being of the land, is part of the Sámi storytelling tradition. Jernslettens academic work is in line with the growing concern that the decolonizing nature entails transcending human-centred expectationalism (Demos, 2016). We suggest, however, in this chapter that this can also be enacted through reading text and acting upon them, and that this is symmetrical to 'academic classics'. We took on the task of reading texts that have never featured in any academic curriculum, novels, whitepapers, or documents or are regarded as research-objects. We propose that these texts not only represent worldmaking, but are also agential entities that have been taking part in worldmaking. The stories that are presented in this chapter come from an ongoing engagement with multiple actors in Sápmi. We therefore live and we learn from engagements with other knowledge holders which de La Cadena (2015) calls co-laboring. This concept inspires scholars to engage in how we take up a responsible engagement with human and nonhuman, stories and stones. We also recognise that local knowledge cannot, with ease, be translated using universalising academic concepts. Indigenous scholars and science and technology studies (STS) have taught us that lesson. 


\section{TWO STORIES OF ENGAGING WITH SIEIDIES}

The first story is of an encounter with Onnegeadgi that occurred some years ago. We two authors and a number of other scholars were visiting one of the Sámi communities for an academic workshop. We were invited for a Sunday walk. This was, at the same time, an ordinary Sunday walk with friends and also 'research'. Three of the participants were scholars who are concerned about the decolonizing of the academy, the two authors of this chapter were also participants and so was the STS scholar John Law with whom we have collaborated with in the past. Below is what academic method calls 'a field note' of this Sunday walk.

Walking toward Muvravárri, we stopped by a resting place on the path. We could sit on logs, or we could use them to stand on them to get a better view of the landscape surrounding us. There was also, with the logs, a round circle of stones perfect for a camp fire. Someone (there were no signs or no notes saying who) had taken responsibility for leaving chopped wood and there was a small plastic bag on a branch nearby, in which there were dry matches and dried bark to make it easy to start a fire. This is not found at most camp sites in the North.

“Can we go closer?” John asked quietly, before approaching the sieidi named Onnegeađgi. All of us just stood silently a respectful distance away before walking closer, fumbling with our bodies and relations toward each other on how to behave respectfully toward the sacred Sámi rock. No instructions were given by our hosts. How should we relate to Onnegeadgi? We needed to figure it out, each individually. We take different tacks, each of us drawing on our previous experience of 'power places', the experience of the place as powerful in some way being shared.

Walking around the rock - Clockwise or the other way? How close? Does the rock itself offer instructions on how to approach? We find cracks, and small pocket-like formations in which there are pieces of reindeer-horn and other objects taken from nature. 
Onnegeađgi is located on trails to the winter pastures of a number of Sámi siidas. Oral stories told about this particular sieidi tell of the Sámi siida moving over this mountain, and leaving different pieces of equipment under the stone. In the spring, when they returned, they greeted and talked to the stone as a person. They would take a glass of liquor, giving the stone one and saying: "this is to you, take a glass with us." Another story tells of an archaeologist who came here a number of years ago to map the site. The range of items left around the sieidi was, at that time, more complex and diverse. The archaeologist removed the items offered to the stone over the years. They have never been returned. People talk about this and worry about new scholar visitors, regret telling the scientist the stories and the location of the stone. The stone is, even so, flagged on maps, and also marked by a signpost that points out trails and directions from the road. It is now storied here and becomes a participant in what happens next in academic research and local story.

We (the authors) searched for stones in old books. We found the following story told to Qvigstad (1928).

If you walk north from Roggilvaggis/Roggildalen, the first river you come to is called Favrisjokka, and then you come to a river divided called Onne-tsjattsa, and a rock called Onnegeađgi. There is a crevice in the rock and there are many horns, coins and other things there. These are objects that people sacrificed to the rock. When Aslak Loggje walked towards the summer pasture and reached Girjegaisa, he would dress up and lower his voice when passing. When he from Roggil passed by on the trails towards summer pasture, he would dress up and ask every person following his ráidu (caravan of reindeer) to do the same. Then he went to the Onnegeadgi, respectfully greeted it and gave the rock the gift of liquid. The dogs were not permitted to bark when the herd was taken into the fence. If they did even so, snow and ice would fall from the mountain that is bent together. If dogs bark, ice will fall and kill the animals. (Qvigstad 1928, p.514-515).

We need to find a way to imagine what we think of as 'the re-domestication of humans by rocks', so that we can deal with the forgotten-ness of the sieidi and nurture a means for the sieidi as a stone and stories of experiencing it as the stone that it is. Sieidis are ontologically multiple, and each 'clot' of such ontological multiplicity is unique. Every sieidi is particular, and in being particular, 
each is subject to what can be imagined as an ontological politics, what it is for differing between different knowledge communities.

This objective requires us to search for a way to connect and also separate 'the natural-social rocks' of modernity that feature in cultural heritage institutional practices and discourses. These are the 'experiential-sublime rocks' of the Sámi institutional practices and discourses. We want to find a way for the rocks to be simultaneously multiple and differentially singular, by inventing a governance tradition that simultaneously enacts differing 'doings' of dissensus and (enough) consensus for government. Achieving this is likely to be complex, messy, and complicated, and involve inventing new institution and governance traditions.

The second story comes from the summer of 2016 and grows out of an experience of Britt. A guided walk is arranged to the sieidi Rikkagallo every year at the festival Isogaisa. Britt signed up for the walk through contacting the guide Eirik, introducing herself as someone who grew up in the area. She also asked for permission to participate based on her research interest. They asked her to meet up with them where the walk would start from.

When Britt arrived, Eirik and other members of his family were waiting in the parking lot for the other participants, who were arriving by bus from the Isogaisa camp. He handed out a three page folder that introduced the walk and how to behave when approaching the sieidi. He also asked Britt to stay close to him and translate what he said into English along the way. $\mathrm{He}$ informed the group of around 30 of the multiple backgrounds and language skills of those participating, advised them to use the two hour walk to prepare for the encounter with the sieidi, and to think about what they wanted to leave behind, an offering or a concern that had brought them on this journey. The first page of the folder told a story noted by Carl Schøyen (1977/1918):

Right in the valley where the people, reindeer and dog trails were, the nomadic 'Lapps' sacrificed offerings to big stones deeply embedded in the soil. Stones that had never been touched by human iron-tools, and were rough and untouched by God's hand. Vuoitas-gallo, the anointed stone, stands in Budalsskaret close to the water drain. Tall and frightening, and surrounded by the cold from the springs that fall in the shadow of the mountain. The accursed stone Rikkagallo is, however, different. It dwells heavily, resting and open in its own valley close to the north of Harvečokka. There are other sacrificial stones and the 
nomads rested in our landscape with these, splattered them with reindeer blood, and brought animals antlers and other gifts to the stones, begging the God in the stone to give them luck, prosperity and good fortune (reindeer luck) on the summer trails. These stones also had an outreached hearing capacity, allowing the Lapps to call upon the stone from miles away and from out in the sea-mountains. Turning to the east and joiking (chanting) to these stones, would strengthen their capacity and the prosperity of their herd.

We started walking along the narrow path into the valley. After ten minutes' walk, we approached 'Ordførerstein'. The name was given to the stone after an event during the depression in the 1930s. National emergency work programs had been established, and road building was one of the tools the program used in the North. In Fossbakken, money was used to build a road into Stormyra. The mayor of Lavangen at that time, Lorents K, came to inspect the road construction. The following story of this event is told on the Digitalmuseum national portal:

The people of Fossbakken were, then as now, a welcoming people. They had dressed for the sour cream porridge, coffee and cakes that were to be served to the guests and the workers, near the old sacrificial stone. Since then the stone in the community has been named the Ordforerstein or the stone of the Mayor (Teigland, 2014).

Eirik took a moment to introduce the walkers to his own story and his relationship to the land we were walking on and the stones we were approaching. His ancestors came from a long line of nomadic Sámi from the tundra of Jukkasjärvi, Pajala and Kiruna, now on the Swedish side. They followed the animals from the tundra in the east to the summer pasture in the sea country or mearrasápmi in the west. There were noaidis from 1500 onwards in his kin lines. Rasu Rasteče was one such. He was both a chief and noaidi, respected and feared. If someone directed a dark intention towards him, then this rebounded and acted upon the sender. He carried out sacrificial acts for the siedi and received sacrifice animals in return. These animals were different from the other animals. They could not be inherited and when the owner died, these animals would return to the place from whence they came. Places nobody knew of. 'When Rasu sensed that his time was out, he sat by the fire 
waiting for the Reindeer of Death to come for him (Brynn \& Brunvoll, 2011, p.39). He spoke to his kin: "The future will be demanding for my people. For this reason, you need to give up the nomadic life and settle in the land west by the sea”. There they would be safe for all time. They did this, and we are many descendants living by the sea. He also told us that there was a sorrow inside him for not speaking Sámi. He elaborates on this statement in the book, by adding that as a child, he embodied a blockage to understanding Sámi. This was connected to that we, as children, had to take on the totality of a Norwegian identity. The Sámi language had no value among the public. I became an adult based upon a normal mainstream North Norwegian identity. The divines in my body can best be articulated as to be - or not to be - a Sámi"' (Brynn \& Brunvoll 2011, p.43-44).

The walk continued, after this introduction, into the valley. The path was narrow, stony and muddy, and people without good waterproof boots struggled. We took several breaks to wait for the inexperienced mountain walkers. We needed to stay together as a group, Eirik said, and take care of our fellow walkers. Three eagles came down from the mountain, circling above us, before leaving. Eirik nodded. This was a good sign.

After two hours of walking, the Rikkagallo appeared before us. In an open valley, surrounded by spiky mountains that are marked on maps using both Sámi and Norwegian names: Siskkitčokka, Basserarri/Rivtind and Muohtačokkka/ Snøtind. Two of Erik's relatives were lying in the moss around the sparkling fire. A spring came up from the soil not far from the sieidi, clear water flowing over the stone. The sun reflected upon the small cave under the waterfall, glimmering pearls of light sparkling off the ground. Water was falling down the rock faces. We drank from hands made into drinking cups. Cold and fresh, as only water from the mountain feels when it enters the mouth before flowing into the body. One of the participant told us that the water had a healing capacity. When he got cancer, he came here to drink. This helped him to fight the sickness of his body. He followed this up by telling a story from some years ago. There were stories that the military troops operating in the nearby heavily militarized community were going to use the stone as target practice. A man ran all the way to Rikkagallo and, standing in front of the stone, told them that they would have to take him out first if they wanted to blow up the stone. They withdrew and the location was then after this officially protected as a heritage site. We were informed how to approach Rikkagallo in the folder we were given. 'At the sacrificial stone, we will hold a ceremony in 
which we call upon the energies of the four directions of heaven, mother earth and the universe. Then we will all walk towards the stone and place the gift we brought into the cleft of the stone'.

\section{GOVERNMENTAL AND LOCAL POLITICS OF RECONCILIATION IN NORWAY}

The Norwegian Parliament on the 20 June 2017, made the decision to establish a commission to investigate the politics of norwegianization and the injustice inflicted upon the Sámi, Kven and Norwegianfinns in Norway. It was stated in the debate held in Parliament, that the main objective of the commission must be to establish a common understanding of the history. It was proposed that the Canadian commission could be used as a model in the scoping of the commission.

Stanton (2017) argues;

The term "reconciliation" in the transitional justice literature is problematic in the Canadian context, since it implies that the parties were once whole, experienced a rift, and now must be made whole again. In colonial settings such as Canada, this is not the case. The relationship between Indigenous and settler peoples in Canada was one of nations encountering nations, where one gradually oppressed and marginalized the other. Indigenous peoples never agreed to the denial of their sovereignty, cultures or identities. Indeed, as noted by Chief Justice McLachlin in Haida Nation: "Put simply, Canada's Aboriginal peoples were here when Europeans came, and were never conquered."Yet this statement by the Chief Justice is not representative of how the larger Canadian population views their history, and nor does it ultimately ground the Court's conception of reconciliation (Stanton, 2017, p.40).

The Sámi Parliament stated that reconciliation, strengthened mutual trust, and a renewal of relationships between the Sámi, the Kven and the Norwegian Society should be achieved in a process built upon respect, acceptance, recognition and international law. Acceptance, acknowledgement and reconciliation not only applies to the relationships between the Sámi, Kven and Norwegians, but also to the acceptance and recognition of that assimilation had different effects on different communities, families and persons. 
The Norwegian and Sámi Parliament statements differ in interesting ways. The Norwegian Parliament envisioned a common understanding of the past. The Sámi Parliament states a need to accept that multiple differences exist between the indigenous Sámi, national minority Kven, and majority Norwegian populations. The Sámi Parliament also strongly believes that there is a need to recognize differences within the Sámi and Kven communities, and that colonial politics had different effects. We propose that this divergence between the statements not only points to ethnopolitical differences, but also to ontological differences (Verran \& Christie, 2011; Blaser, 2009). Considering differences to be ontological recognizes the need to make translations, to elaborate workarounds, and protocols. This, furthermore, proposes dialogue as negotiation, in which both sides commit to being changed, actively disagreeing on some issues while agreeing on others. The preparatory meetings focussed on creating a space in which stories can be told, and in which truth can 'at last' be articulated in public. A number of the speakers who participated in the meeting claimed that this was important to them. It also meant that they came to these meetings to tell untold stories that were a part of their family past, and present in the time of assimilation.

We have argued that the local practice of telling the truth relates to an earnestness and seriousness about the present. This is a practice that asks participants, both the teller and those present in and within the story, to slow down and be in the rhythm of this moment and what it can tell. This is part of reconciliation in practice. There is also a need to address local engagement in reconciliation events, and to pursue reconciliation as a governmental political project. It is all too tempting to see history as a series of defining moments and critical events that need to be mapped or retold for reconciliation to occur. Remembrance transforms maps, polities, and worldviews. Many often declare, in the aftermath of this, that nothing will ever be the same again. Yet we need to rethink history. Only past events that are continually transmuted into myth appropriate the past, and in doing so revise the way the past appears to us. We are, even so, alive to the ways in which the present, replete with its own preoccupations, struggles, and interests, revises the way we see the past.

What should we therefore epistemically make of our stories of journeying, being in the presence of rocks, and then finding and reading stories of these rocks in old books? We want to find a way to deal with the oblivion suffered by many of these rocks of the north. Stories are in part told to bring forth knowledge from the past. They however involve more than this. Sieidies, Sámi 
secret stones and their stories, make evident the existence of the land of dormant reciprocity. We therefore present our stories of sieidies as examples of the many storied experiences that recall the stone's being as part of the Sámi land. We enact respect and care in recognizing other stories and of how they have, in other times, healed land, animals and people. The stories seem banal. However, letting the banality interrupt the insistence of these storied experiences is what unlearning privilege and staying with the ontological trouble is.

\section{LITERATURE:}

Äikäs, T., Puputti, A., Núñez, M., Aspi, J., \& Okkonen, J. (2009). Sacred and Profane Livelihood: Animal Bones from Sieidi Sites in Northern Finland. Norwegian Archaeological Review, 42(2), 109-122.

https://doi.org/10.1080/00293650903289641

Äikäs, T. \& Salmi, A. (2013). The Sieidi is a Better Altar/the Noaidi Drum's a Purer Church Bell': Long-term Changes and Syncretism at Sámi Offering Sites. World Archaeology 45(1), 64-82. https://doi.org/10.1080/00438243.2012.759510

Bergman, I., Östlund, L. Zackrisson, O. \& Liedgren, L. (2008). Varro Muorra: The Landscape Significance of Sami Sacred Wooden Objects and Sacrificial Altars. Ethnohistory 55(1), 1-28. https://doi.org/10.1215/00141801-2007-044

Blaser, M. (2009). Political ontology. Cultural Studies 23(5/6), 873-896. https://doi.org/10.1080/09502380903208023

Brynn, G. \& Brunvoll, B. (2011). Eirik Myrbaug Sjaman for livet. Oslo: Nova forlag. Danius, S., Jonsson, S. \& Spivak, G. C. (1993). An interview with Gayatri

Chakravorty Spivak. Boundary, 20(2), 24-50.

https://doi.org/10.2307/303357

de la Cadena, M. (2015). Earth Beings, Ecologies of practice across Andean worlds.

Durham and London: Duke University Press. https://doi.org/10.1215/9780822375265

Demos, T. J. (2016). Decolonizing Nature. Contemporary Art and the Politics of Ecology. Berlin: Sternberg Press.

Fonneland, T. (2017). Contemporary Shamanisms in Norway. Oxford: Oxford University Press. https://doi.org/10.1093/oso/9780190678821.001.0001 Haraway, D. (2016). Staying with the Trouble. Making Kin in the Chtbulucene.

Durham \& London: Duke University Press.

https://doi.org/10.1215/9780822373780 
Heinämäki L. \& Herrmann T. (Eds). (2017). Experiencing and Protecting Sacred Natural Sites of Sámi and other Indigenous Peoples. Cham: Springer Polar Sciences. Springer.

Jackson, M. (2002). The politics of storytelling. Violence, transgression and intersubjectivity. Copenhagen: Museum Tusculanum Press.

Jernsletten, J. (2010). Bissie dajue: relasjoner mellom folk og landskap i Voengel-Njaarke sijte. $\mathrm{PhD}$ dissertation. University of Tromsø, Tromsø.

Jernsletten, K. (2012). The hidden children of Eve: Sámi poetics guovtti ilmmi gaskkas. $\mathrm{PhD}$ dissertation. University of Tromsø, Tromsø.

Joks, S. \& Law, J. (2017). Sámi salmon, state salmon: TEK, technoscience and care. The Sociological Review, 65(2):150-171. https://doi.org/10.1177/0081176917710428

Kramvig, B. \& Verran, H. (2016). Gender and indigeneity as generative differentiations - Reflections on reconciliation, violence and storytelling in Sápmi. Tidsskrift for Kjønnsforskning, 40(03-04), 55-66.

https://doi.org/10.18261/issn.1891-1781-2016-03-04-05

Kramvig, B. \& Pettersen, M. (2016). Living land, Below as Above. Living Earth, Fieldnotes from the Dark Ecology Project. Amsterdam: Sonic Act Press, 131-141. Kuokkanen, R. (2010). The Responsibility of the Academy: A Call for Doing Homework. Journal of Curriculum Theorizing, 26(3), 61-74.

Lund, J. (2015). Living Places or Animated Objects? Sámi Sacrificial Places with Metal Objects and Their South Scandinavian Parallels. Acta Borealia 32(1), 20-39. https://doi.org/10.1080/08003831.2015.1029846

Oakeshott, M. (1933). Experience and its modes. Cambridge: Cambridge University Press.

https://doi.org/10.1017/CBO9781316286494

Olsen, K. (2017). What Does the Sieidi Do? Tourism as a Part of a Continued Tradition? In Viken, A. \& Müller, D. (Eds.), Tourism and Indigeneity in the Arctic (p. 225-246). Bristol: Channel View Publications. https://doi.org/10.21832/9781845416102-015

Manker, E. (1957). Lapparnas heliga ställen: kultplatser och offerkult i belysning av Nordiska museets och Landsantikvariernas fältundersökningar. Stockholm: Gebers.

Mathisen, S. R. (2010). Narrated Sámi Sieidis. Heritage and Ownership in Ambiguous Border Zones. Ethnologia Europaea. Journal of European Ethnology, 39(2), 11-25.

Minde, H. (1998). Constructing 'Laestadianism': A case for Sami survival? Acta Borealia, 15(1), 5-25. https://doi.org/10.1080/08003839808580472 
Miller, B. (2007). Connecting and correcting: a case study of Sami healers in Porsanger. Leiden Department Cultural Anthropology. Social and Behavioural Sciences: Leiden University.

Mol, A., Moser, I. \& Pols, J. (2010). Care: Putting practice into theory. In Mol, A. Moser, I. \& Pols, J. (Eds.). Care in practice on tinkering in clinics, homes and farms transcript. (p. 7-27) Bielefeld: Transcript Verlag.

Mulk, I. (1996). The Role of the Sámi in fur trading during the late Iron Age and Nordic medieval period in the light of the Sámi sacrificial sites in Lapland, Northern Sweden. Acta Borealia, 13(1), 47-80. https://doi.org/10.1080/08003839608580447

Myrvoll, M. (2017). Gosa bássi várit leat jávkan? Where have all the sacred mountains gone? In Heinamäki, L. \& Herrmann, T. (Eds.), Experiencing the Sacred Arctic: Sacred Sites, Indigenous Peoples and the Law. (p. 101-116). Cham: Springer. https://doi.org/10.1007/978-3-319-48069-5_7

Qvigstad, J. (1928). Lappiske eventyr og Sagn II. Oslo: Aschehoug.

Reinert, H. (2016). About a Stone: Some Notes on Geologic Conviviality.

Environmental Humanities, 8(1), 95-117.

https://doi.org/10.1215/22011919-3527740

Schøyer, C. (1977/1918). Tre stammers mote: av Skouluk-Andaras beretninger. Oslo: Gyldendal.

Stanton, K. (2017). Reconciling Reconciliation: Differing Conceptions of the Supreme Court of Canada and the Canadian Truth and Reconciliation Commission. Journal of Law and Social Policy, 26, 21-42.

Teigland, J. (2014). Samisk offerstein - Ordforersteinen https://digitaltmuseum. no/011085441780/samisk-offerstein-ordforersteinen

Verran, H. \& Christie, M. (2011). Doing Difference Together. Culture and Dialogue, 1(2), 21-36.

Verran, H. (2015). Governance and Land Management Fires Understanding Objects of Governance as Expressing an Ethics of Dissensus. Learning Communities: International Journal of Learning in Social Contexts. 15, 52-59. https://doi.org/10.18793/LCJ2015.15.09

Winthereik, B. \& Verran, H. (2012). Ethnographic Stories as Generalizations that Intervene. Science Studies, 25(1), 37-51.

Østmo, L. \& Law, J. (2017). On land and lakes: Colonizing the North. Technosphere Magazine. https:/www.technosphere-magazine.hkw.de/p/ On-Land-and-Lakes-Colonizing-the-North-9A4jWt7o4FgCDSxZmTvjKz 